\title{
В.В. Федюшин
}

\section{К ВОПРОСУ ОБ УСТРОЙСТВЕ АДМИНИСТРАТИВНОЙ СИСТЕМЫ МАЙЯПАНСКОЙ ДЕРЖАВЫ}

\begin{abstract}
Статья посвящена изучению административной системы Майяпанской державы. Автор исходит из необходимости критически использовать имеющиеся данные о политической организации постмайяпанских образований. В частности, критике подвергнуто историографическое представление о происхождении «провинций» контактного периода из административных частей Майяпанской державы. Доказывается, что минимальной и вездесущей единицей политической организации как майяпанского, так и контактного периода являлось небольшое образование номового типа - ках. Его внутреннее деление на административнополитические (кучтеель) и географические (какаб) составляющие не претерпело изменений в течение позднего постклассического периода.

Ключевые слова: майя; Юкатан; постклассический период; политическое устройство.
\end{abstract}

Майяпанская держава - последнее крупное доиспанское политическое образование на территории Юкатанского полуострова, существовавшее в XIII - первой половине XV в. Историческая память о нем ко времени конкисты стала важным элементом идеологии правящих династий северо-западной части полуострова, но касалась преимущественно организации высшего уровня власти. Вместе с тем организация управления входившими в состав политии подчиненными или ассоциированными территориями представляет не меньший интерес, чем функционирование верхнего уровня политической системы.

При попытке ответить на вопрос о политической организации Майяпанской державы нельзя обойтись без изучения реалий контактного периода (вторая четверть XVI в.), наиболее полно отраженных в испанских и индейских письменных источниках. Необходимо, конечно, отдавать себе отчет в том, что от падения Майяпана до завоевания полуострова испанцами прошло столетие, и внешне ситуация кардинально изменилась: к XVI в. на Юкатане существовало несколько десятков политических образований разной величины. Однако эволюция нижних уровней управления не могла быть столь же резкой, как в случае с верховной властью. Косвенно об этом говорит тот факт, что знать, принадлежавшая разным политиям, находившимся зачастую в конфликтных отношениях, была в значительной степени едина. Единство это выражалось как в породненности большинства правящих линиджей [1. Р. 21-32], так и в наличии общего сословного сознания, проявлявшегося, в частности, в однородности архитектурного и изобразительного стиля и религиозных практик (к примеру, паломничества к общим священным местам [2. Р. 152-182, 195-198; 3. Р. 81-87, 150-152]). Формы политической организации майя северного Юкатана первой половины XVI в., несмотря на многочисленность независимых политий разного размера, также не имели сильных региональных отличий [4. Р. 42-43; 5. Р. 76]. Bсе это говорит о том, что социальная и политическая структура майя-юкатеков сформировалась либо до, либо во время существования Майяпанской державы. Потому при изучении нижних уровней управления последней нельзя обойтись без относительно богатого материала середины XVI в.

Наиболее четким проявлением былой административной системы Майяпанской державы вплоть до второй половины XX в. считалось разделение полуострова на полтора десятка относительно крупных территориальных единиц, чему немало поспособствовала раннеколониальная терминология: в раннеколониальных источниках эти земли известны как «провинции» (см., напр., [6. С. 110 и далее]; рис. 1). С данной предпосылкой тесно было связано другое представление - о том, что «провинции» XVI в. являлись действительными политическими образованиями.

Однако зафиксированное в раннеколониальных источниках деление лишь отчасти коррелировало с реальной политической ситуацией. Несмотря на попытки американского антрополога Р. Ройса представить «провинции» в роли действительных политических единиц, пусть и разного устройства [7. Р. 3, 6-8], более поздние работы мексиканского историка С. Кесады [1. Р. 6] и его японского коллеги Ц. Окоши Харады [8. Р. 86-88] заставляют отказаться от такого их рассмотрения. Действительно, некоторые из «провинций», судя по всему, были объединены под властью одной династии (к примеру, Ах-Кануль, Мани, Сотута, Ах-К'ин-Чель). Однако большинство их отличала крайне слабая либо нулевая внутренняя политическая интеграция [1. Р. 138-139].

Отнюдь не все «провинции» середины XVI в. могли входить в состав Майяпанской державы. Это касается не только отдаленных южных областей Юкатана, но и северо-восточного побережья. Так, в «Сообщении из Вальядолида» 1579 г. ${ }^{1}$ говорится, что «в древности индейцы провинции Чикинчель называли этих [индейцев] вильи ${ }^{2}$ Вальядолид и провинций Купуль и Кочвах $a x$ майя, оскорбляя их [этим] как людей подлых и низких, злобного рассудка и наклонностей» [9. Т. 2. Р. 37]. Эта 
же информация повторяется в «Сообщении из Пополы, Синсимато и Самьоля» [9. Т. 2. Р. 216]. Впрочем, надо отметить, что последний документ принадлежит перу главного алькальда Вальядолида Диего Сармьенто де Фигероа, бывшего по крайней мере редактором «Сообщения» и из самой вильи. В приведенное им значение слова «майя» поверить сложно, однако вряд ли стоить ставить под сомнение, во-первых, сам факт такого именования туземцев Купуля и Кочваха жителями Чикинчеля, а во-вторых, враждебное отношение жителей этой «провинции» к ахмайя. Само это определение является, несомненно, политонимом, который в данном случае сохранился в обиходе жителей, очевидно, некогда пограничного и не зависящего от Майяпана региона [10. Р. 29-30].

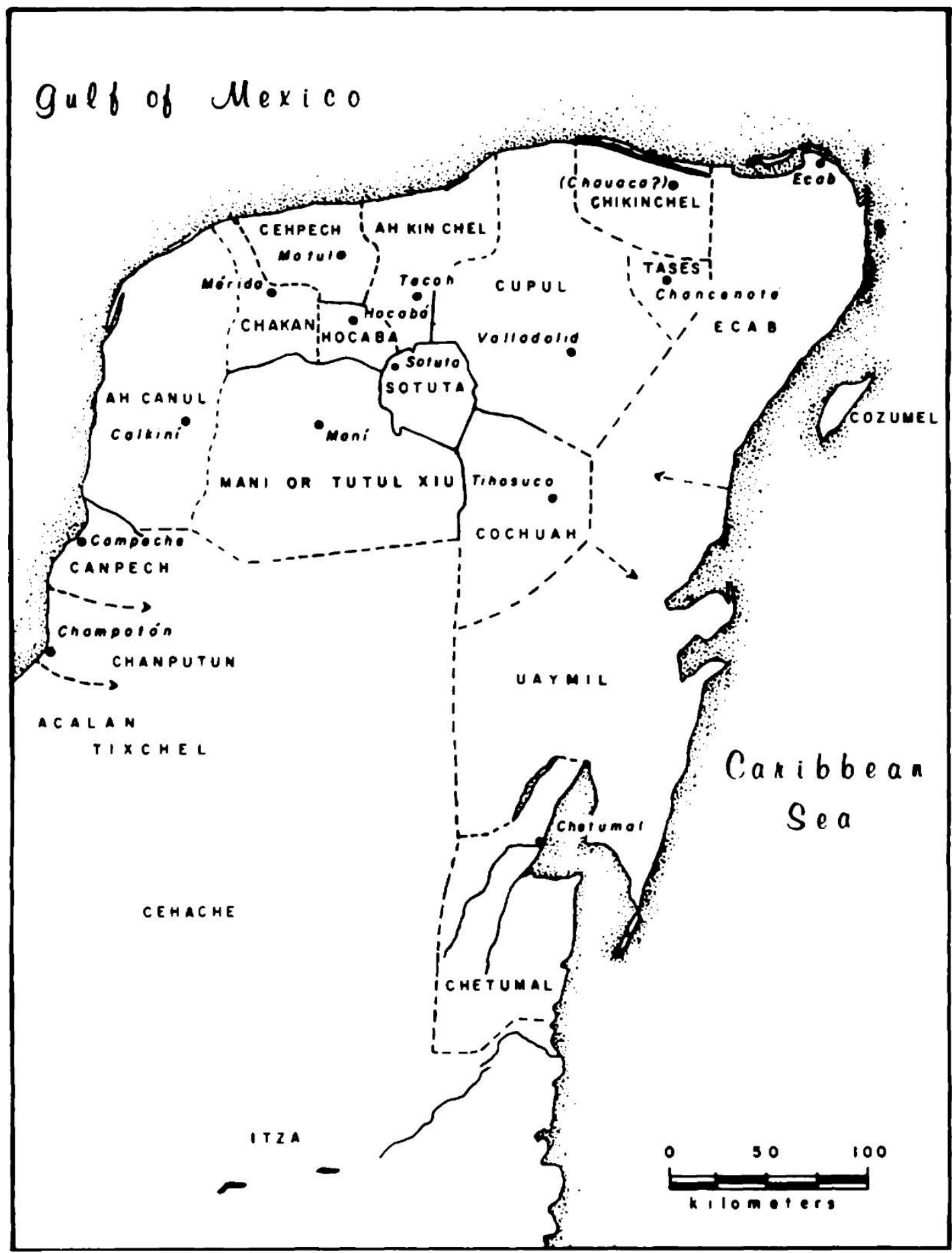

Рис. 1. «Провинции» периода конкисты (реконструкция Р. Ройса с дополнениями Э. Эндрюса). Источник: Andrews A.P. The Political Geography of the Sixteenth Century Yucatan Maya: Comments and Revisions // Journal of Anthropological Research. Vol. 40, is. 4. P. 589-596

Представляется, что деление на «провинции» (по крайней мере в том виде, в каком оно дошло до нас в испанских источниках) отражает не политическую картину позднего постклассического Юкатана, а устоявшееся в общественном сознании майя разделение полуострова на «земли», частично обусловленное политическими 
(Мани, Сотута), частично - культурными и этническими (Ах-Кануль, Чикинчель) отличительными чертами [11. С. 95-96]. Поэтому данную категорию из анализа политико-административных структур придется исключить.

Основной политической, а также территориальноадминистративной единицей эпохи конкисты являлось небольшое образование номового типа, состоявшее из селения и его непосредственной сельскохозяйственной округи - ках (юк. cah). Термин cah, переводимый испанцами как «селение» (исп. pueblo) [12. Р. 170], относился, по-видимому, в первую очередь именно к номовому центру. Известные словари колониального времени рядом выражений прямо подтверждают данную мысль. В частности, во всех из них noh cah переводится с незначительными вариациями как «город или большое селение» [Ibid. Р. 59, 164; 13. Fol. 61r; 14. P. 245; 15. Fol. 68r, 144r]. Противоположное по смыслу значение - «маленькое селение» - также образуется при помощи слова cah: chanchan cah $[12$. P. 164; 13. Fol. 61r; 15. Fol. 14v, 144r, 180v] или pet cah [13. Fol. 374r; 15. Fol. 14v, 144r). Однако ряд свидетельств заставляет расширить эту трактовку. «Сообщения с Юкатана» не делают разграничения между самим центром и подчиненной ему территорией. Зачастую термин pueblo используется в них для обозначения не только селения, но и подвластной ему округи [11. С. 94-95]. Стоит отметить «Сообщения» с восточной части полуострова, где присутствует формула con sus sujetos («со своими подчиненными [селениями]») [9. Т. 2. Р. 197, 215, 216, 218, 231, 232, 246, 283, 320]. Скорее всего, их составители попросту не видели смысла в именовании и каком-либо выделении селений, подчиненных кахам. Это заставляет полагать, что номовый центр (cah) в эпоху конкисты с точки зрения организации политической жизни был очень плотно интегрирован с подчиненными ему мелкими поселениями, обладая над ними полным суверенитетом. Такая интеграция не вызовет удивления, если обратить внимание на размеры этих общностей. Приводимые энкомендеро ${ }^{3}$ в «Сообщениях» размеры поселений весьма скромны. Так, к примеру, Чавакха ко времени осуществления раздела земель между конкистадорами насчитывала 600 податных индейцев [Ibid. Р. 246] (что дало бы 2 000-2 500 человек в целом [16. Р. 29]), Цонот 600 [9. Т. 2. Р. 84], Тисимин - 600 [Ibid. Р. 284], Чансеноте - 600 [Ibid. Р. 246], Темуль - более 500 [Ibid. P. 102], Исамаль - 500 [Ibid. Т. 1. Р. 304], Таби - 400 [Ibid. Р. 165], Кехак - 400 [Ibid. T. 2. Р. 284], Кинакама - 400 [Ibid. T. 1. P. 375], Китилькум и Кавич - 400 вместе [Ibid. P. 180], Чунхухуб - более 300 [Ibid. Р. 165], Вайма - 300 [Ibid. T. 2. Р. 170], Кициль и Ситильпеч - 300 вместе [Ibid. Т. 1. P. 198], Чечимила - 200 податных [Ibid. T. 2. Р. 250], Кантунилькин - 120 [Ibid. P. 170], Какальчен - 100 [Ibid. Р. 284]. Близка им численность селений, входивших в состав государства ица (от нескольких сотен до 2 тыс. жителей в конце XVII в.) [17. Р. 61], и независимой политии лакандонов в Петене (приблизительно 3 тыс. человек в 1630 г., около 1 тыс. человек в 1695 г.), аналогичной по своей организации каху Северного Юкатана [18. Р. 165].

Еще Р. Ройс обратил внимание на упоминаемый в словаре из Мотуля термин кучтеель (юк. cuchteel). Термин этот многозначен, но выражает в целом понятия одной семантической категории - подчиненности. Так, применительно к человеку cuchteel может означать «подданный, вассал, находящийся под управлением другого», «семья или люди, которых кто-либо имеет в доме», «прихожанин»; с другой стороны - и «подразделение, часть селения» [13. Fol. 87v]. Р. Ройс, дословно приняв последний вариант, определил кучтеель как «мельчайшую организационную единицу, округ (ward) или район (barrio) поселения» [7. Р. 7]. Такая трактовка кучтееля, вписывающая его внутрь центрального поселения каха, представляется поверхностной. Стоит иметь в виду, что словарь из Мотуля, равно как и прочие францисканские словари, составлялся спустя достаточно долгое время после осуществления редукций [19], в ходе которых множество поселений насильственно сводилось в одно. Неудивительно, что прежняя социальная организация могла выражаться по-новому, уже в географическом делении поселения-редукции. Следовательно, нет нужды рассматривать кучтеель в качестве элемента поселенческой организации внутри главного селения каха, как делал это Р. Ройс.

Кучтеель (соседскую общину, состоявшую из нескольких большесемейных коллективов) на более высоком уровне представлял ахкучкаб (ah cuchcab) - по определению францисканского словаря XVI в. из Мотуля, «индеец-принципал (indio principal), которому поручена некая часть [селения] для сбора подати и прочих дел общины (cosas de comunidad)» [13. Fol. 11v, 12r]. Очевидно, синонимичен ему другой термин - $a x$ чунт'ан (ah chun than), переводимый как «принципал селения» [Ibid. Fol. 15v]. Сложно сделать окончательный вывод о природе власти ахкучкаба. С одной стороны, полномочия, перечисленные в процитированном отрывке, не выходят за пределы полномочий должностных лиц. Так его рассматривает, к примеру, С. Кесада [1. Р. 20]. Однако представляется, что ахкучкаб в доиспанское время мог играть куда большее значение, быть наиболее знатным представителем соседской общины и именно потому представлять ее перед двором батаба. По крайней мере в раннеколониальных источниках мы почти не встречаем, кроме одного случая, упоминаний назначения ахкучкабов правителями селений. Этот единственный случай - «Сообщение из Синанче и Эгума». Его составитель Хуан де Ла Камара, однако, четко указывает на то, что ахкучкабы выбирались правителем из наиболее знатных представителей кучтеелей («dividian el pueblo por sus barrios... y nombraban un hombre rico $y$ hábil [para que] tuviese cargo de cada uno de ellos») [9. T. 1. P. 123]. Стоит отметить и сам факт того, что ахкучкабы именуются принципалами: это подчеркивает их высокое положение в обществе [13. Fol. 11v, 12r; 9. T. 1. P. 110 et passim]. Немаловажным представляется и свидетельство 
составителей «Сообщения из Мамы и Кантемо» (в числе которых указан и представитель местной знати Алонсо Печ) о том, что наряду с касиками (общий термин, относящийся к правителям, но тяготеющий к батабу [11. С. 100-101]) существовали принципалы, которые «имели под своей рукой индейцев», располагали собственными святилищами, контролируя, таким образом, отправление культа [9. Т. 1. Р. 110].

В то же время источниками - как испанскими, так и юкатекскими - зафиксирована другая территориальная и, возможно, административная единица, входившая в состав каха - какаб. Словари дают достаточно определенное значение: «предместье» (исп. arrabal) [12. Р. 19], «маленькое селение» (исп. pueblo pequeño [13. Fol. 60r]), «деревня» (исп. aldea [15. Fol. 14v]), «местечко» (исп. lugarillo [15. Fol. 144v]). О земледельческом характере какаба говорит и зафиксированное в словаре из Мотуля выражение cacab luum - «плодородная земля» [13. Fol. 60r].

Подчиненность, вхождение какабов в состав каха очевидны. В рассказе о приходе ица в Юкатан, содержащемся в книге Чилам-Балам из Чумайеля, какабы значатся в числе неотделимых частей каха как территориальной единицы: «kabanzah peten u caahoob, kabanzah cheen u caahoob || kabanzah cacab u caahoob, kabanzah luum и caahoob» («они назвали части своих кахов... сеноты ${ }^{4}$ своих кахов... какабы своих кахов... землю своих кахов») [20. Р. 225]. В то же время известны два топонима, образованных от данного корня - Цуккакаб (юк. tzuc cacab - «несколько / больше одного какабов» [21. Р. 29, 132-133]) и Нохкакаб [7. Р. 15; 22. Р. 40, 88]. Вполне вероятно, что Цуккакаб имел статус каха - так, его представитель Хуан Вициль с титулом ah canan (от юк. canantah - «охранять») в 1557 г. участвовал в съезде правителей при разделе земель в Мани [21. Р. 62-63].

В связи с этим встает вопрос о соотношении кучтееля и какаба. На первый взгляд эти термины выглядят чуть ли не синонимами и обозначают определенную часть каха. Однако с этой точкой зрения можно поспорить.

Как справедливо указывает С. Кесада, из четырех приведенных значений слова cuchteel в майяских текстах практически повсеместно встречается лишь одно - «вассал, подчиненный» [1. Р. 7-11]. Лишь в одном весьма спорном месте хроники из Калькини можно допустить (как делает это Ц. Окоши Харада) понимание термина cuchteel в географическом смысле. Отрывок этот заслуживает внимания. Речь идет о выходе знатных династий из разрушенного Майяпана. Текст выглядит следующим образом: «...Na Chan Che || Na May Tayu \| Na Pot Canche $\|$ Ah Kul Couoh $\uparrow \|$ yetel ah cupul \| yetel ah quepech $\| u$ ch'aci u cuchteel || ah xiuob lae» («Начан-Че, Намай-Тайю, Напот-Канче, Ахкуль-Ковох, и Купули, и Кехпечи $\underline{c h}$ 'aci кучтеель Шивов») [22. Р. 87]. Глагол ch'aci, как делает Баррера Васкес, можно перевести как «разрушили». Однако сведений о войнах перечисленных групп с Шивами сразу после падения Майяпана у нас нет. Напротив, Печи, Купули и тем более Ковохи, скорее всего, состояли с ними в союзнических отношениях [23]. Уместной с точки зрения соответствия содержания другим источникам выглядит версия Ц. Окоши Харады, также возможная: «...прошли по кучтеелям Шивов» [22. Р. 87 п. 220]. В данном случае очевидна географическая локализация кучтееля. Впрочем, на основании лишь одного свидетельства рано делать выводы: в конце концов отрывок записан в 1594 г. [Ibid. Р. 86], и связанное с локализацией (и, возможно, вызванное колониальной политикой сведения кахов в редукции [24. Р. 158-191]) значение термина уже могло закрепиться в языке майя.

В остальном же, если не брать во внимание этот отрывок (надежность которого, как видно, остается спорной), представляется верным считать термин cacab относящимся к географии, поселенческой структуре, a cuchteel - к административной и социальной структуре каха. Вполне вероятно, что зачастую они могли полностью накладываться друг на друга.

Важно отметить, что части каха могли иногда играть самостоятельную роль. Фрагмент легендарной истории Экбалама, приведенный в «Сообщении» из данного поселения, смешивает целый ряд правителей классического периода в собирательный образ Коч-Каль-Балама и обозначает пять древних храмов как «здание» самого КочКаль-Балама и четыре, выстроенные «другими сеньорами и капитанами», которые «признавали Коч-Каль-Балама сеньором, и он был высшим [правителем]» [9. Т. 2. Р. 138]. Сложно не увидеть за фигурой мифологизированного правителя и четырех подчиняющихся ему «капитанов» внутреннее деление крупной общины-каха на более мелкие части. Название селения Тихоцук (юк. $t i$ ho $t z u c$ ), верно истолкованное его энкомендеро Антонио Мендесом как «пять частей» [Ibid. Р. 198], также свидетельствует в пользу его образования в результате синойкизма отдельных общин (то же можно сказать об уже упоминавшемся Цуккакабе). И, напротив, «Сообщение из Кикиля» информирует об отселении «нескольких частей» (исп. algunas parcialidades) из-за нашествия саранчи [Ibid. P. 267].

Базовой ячейкой общества постклассических юкатеков, несомненно, была большая семья, находившаяся под властью патриарха. Словарь из Мотуля называет его ah chun cahil, [ah] chun na и [ah] chun otoch, что во всех случаях переводится как «господин дома или отец семейства» [13. Fol. 15r, 445r]. К сожалению, нет какихлибо других свидетельств, которые бы указывали на права, обязанности и политико-административные функции (если они были) главы большой семьи. Юкатекское название такой единицы тоже до конца не ясно: ему может соответствовать большое количество терминов. Ц. Окоши Харада склоняется к варианту cuchcabal [25. Р. 208 n. 1], что вполне оправданно [13. Fol. 86r]; cuchteel [Ibid. Fol. 87v) и мек'ельте (юк. mekelte) [Ibid. Fol. 304r] также могут, согласно словаря из Мотуля, обозначать большую семью.

Наиболее сложной формой политии на Юкатане эпохи конкисты являлся кучкабаль (термин омонимичен приведенному выше, но, несомненно, имеет другое 
значение). В ряде случаев кучкабаль представляется взаимозаменяемым по отношению к «провинции» термином. Автор словаря из Мотуля переводит выражение u cuchcabal Maní, Mutul как «провинция или комарка Мани, Мотуля и т.д.» [13. Fol. 86r]. Несмотря на то, что термин cuchcabal в испаноязычных источниках, кроме словарей, не употребляется, в «Историко-географических сообщениях» он зачастую передается с помощью термина provincia [11. C. 95-96].

Правитель кучкабаля на Северном Юкатане именовался халач-виником (юк. halach uinic). В колониальную эпоху применение этого термина претерпело изменения, но смысл его (правитель более высокого ранга, нежели правители отдельных кахов) остался: так, в словаре из Мотуля halach uinic обозначает высокие посты уже в колониальной администрации - должности епископа и губернатора [13. Fol. 176v].

Размеры кучкабалей, судя по всему, могли достаточно сильно варьировать. Так, кучкабаль Мани, одно из крупнейших политических образований юкатеков к началу конкисты, включал в себя около двух десятков селений-кахов [26. Р. 53]. 17 «селений» находилось во власти Начи-Кокома, правителя кучкабаля Сотута [27. С. 208]. В других регионах Юкатана аналогичные политические образования могли достигать более крупных размеров. Так, власть столицы петенских ица Нохпетена, согласно списку селений, указанному последним его правителем Кан-Эком, распространялась на 53 селения [17. Р. 62-63]. Акалан, другое крупное государство, охватывавшее юго-западную часть Юкатана, имел в своем составе 76 селений-кахов [28. Р. 290-292]. Население кучкабаля в среднем составляло несколько десятков тысяч человек. Так, ценз 1549 г. относительно населения кучкабаля Сотута дает цифру в 15 тыс. человек, Мани - 32,5 тыс. чел [27. С. 208]. Г. Джонс рассматривает цифру в 48 тыс. человек как в целом соответствующую общей численности населения Петена, большую часть которого занимало государство ица, по размерам и устройству напоминающее североюкатанские кучкабали [17. Р. 137].

В рамках кучкабаля, вероятно, осуществлялось совмещение военно-политической власти с религиозной. По вполне объяснимым причинам раннеколониальные источники по Северному Юкатану обходят связь между политической и религиозной властью стороной. Связано это, скорее всего, со стремлением знатных династий (которые и поставляли большую часть историкоэтнографических сведений испанцам) «откреститься» от участия в языческих ритуалах. Однако «Сообщения с Юкатана» указывают на наличие высших жрецов, ахк'инов (юк. ah kin), в столицах кучкабалей - Сотуте [9. Т. 1. Р. 146], Саки [Ibid. Т. 2. Р. 43-45], на Косумеле [Ibid. P. 187]. Наиболее очевидно такое положение для политии ица в Петене, где верховная власть, приобретая черты дуальности, осуществлялась двумя родственниками (двоюродными братьями), носившими одно имя: ахав Кан-Эк и ахк'ин Кан-Эк [17. Р. 104]. Вполне возможно, что жрецы отдельных кахов находились в прямой зависимости от верховного жреца, проживающего в столице, как это следует из источников, касающихся петенских ица [17. Р. 104].

Административный аппарат под управлением $x a$ лач-виника насчитывал, судя по всему, десятки человек. Так, в «Своде законов Начи Кокома» кроме самого правителя в списке придворных упоминаются 2 «принца», 5 главных жрецов, 5 военачальников («генералов»), 3 знахаря, 2 жреца и совет с неизвестным числом участниковвсего, по меньшей мере, 17 человек, не считая совета [29. Р. 131-132]. Данные этого, безусловно, позднего документа подтверждаются сведениями о государстве ица в Петене, прослойка высшей знати которого включала в себя несколько десятков человек, по меньшей мере 22 из которых были членами совета при правителе [17. Р. 84-86].

Подчиненные батабы вынуждены были платить дань халач-винику. Значительная часть натуральных податей была сопряжена с календарем и сельскохозяйственным циклом. «Сообщения с Юкатана» упоминают хлопковые накидки [9. Т. 1. Р. 69], кур, маис, мед [Ibid. P. 269], воск, чили, фасоль, дичь [Ibid. Р. 133-134, 274], и хотя эти товары перечисляются в разных комбинациях, смысл в них вкладывается повсюду один: «От всего, что производила земля, они давали такому правителю в знак признания его сеньории» [Ibid. P. 274]. Не вызывает сомнения, что подача подобных сведений была выгодна как составителям «Сообщений» (лишний раз демонстрируя распространенность сбора дани среди доиспанских майя и, следовательно, приемлемость податей в рамках энкомьенды), так и самим индейцам (в условиях резкого упадка торгового обмена после конкисты [30] наиболее удобным видом платежей для кахов, безусловно, была поставка продуктов натурального хозяйства) [31. С. 38-39]. В то же время в отдельных местах информаторы создают совсем уж идиллическую и неправдоподобную картину: так, автор «Сообщения из Сотуты и Тиболона» пишет о том, что подать была не больше одной курицы с индейца в год [9. Т. 1. Р. 146], а в «Сообщении из Цана, Панабчена и Моны» и вовсе говорится о том, что «дань была очень ограниченной и почти добровольной», «не более чем признанием его [халач-виника] сеньории» [Ibid. T. 2. Р. 252-253]. Вряд ли это правда. Так, в «Сообщениях» с восточной части полуострова все-таки говорится и о том, что в качестве дани правителю передавали престижные товары, явно не входившие в урожай обычного общинника. В частности, называются цветные драгоценные камни или, скореe, ракушки (cuzcas coloradas) [Ibid. P. 37, 44, 86, 126, 298], прямо говорится, что это была «их монета» [Ibid. Р. 323], а также жад [Ibid. P. 323]. Можно предположить, что в рамках Майяпанской державы доля дани, выплачиваемая ценными средствами обмена, могла быть выше, чем в середине XVI в., как за счет куда более развитой дальней торговли [32. Р. 269-424], так и в силу географической 
отдаленности периферийных районов, снижающей выгодность доставки продуктов натурального хозяйства [Ibid. P. 405-407]. В то же время в словарях зафиксирован и другой вид дани. Речь идет о податях шимте (ximte), лот (lot) и лоч-ломтах (loch lomtah); о шимте известно, что она платилась бобами какао [13. Fol. 459v, 273r, 271v]. Как замечает А.В. Пакин, примененный составителем словаря термин деррама относится к нерегулярным, экстренным сборам [33. Р. 67]. Не последнее значение в служении халач-винику, естественно, имело предоставление батабами ему военных отрядов [29. Р. 130-131].

Таким образом, к моменту прихода испанцев в политико-административном устройстве общества майяюкатеков можно проследить три, местами - четыре уровня. Из них большая семья и соседская община (кучтеель) вряд ли имели политическое значение; последняя, впрочем, в исключительных ситуациях (отселение, объединение с другими общинами) могла выступать как отдельная политическая единица. Впрочем, практически сразу кучтеель вливался в уже существующую или входил в новосозданную общинную структуру каха, административной частью которого являлся.

Ках являлся базовой территориальной и политической единицей майя-юкатеков и включал в себя от нескольких сотен до нескольких тысяч человек. Состоял он из ряда соседских общин (кучтеелей), объединенных вокруг одного центра. Вряд ли такая полития могла быть самодостаточной, существовать вне окружения подобных или более сложных обществ. Исследователя не должна смущать политическая «независимость» отдельных кахов: знать любого политического образования была связана с правящим классом других политий посредством брачных союзов, регионального обмена и через общие для представителей господствующих линиджей всего Юкатана религиозно-идеологические практики. Сословие знати на всем полуострове в известной степени оказалось единым, и вряд ли эта унификация могла произойти после уничтожения Майяпанской державы.

В ряде случаев кахи могли выступать в роли независимых политий, как это было в Чикинчеле и Чакане, однако в большинстве своем они оказывались инкорпорированы в более сложные региональные структуры кучкабали. Судя по всему, организация власти на уровнях кучкабаля и каха была весьма сходной, различаясь прежде всего в размерах двора, войска и т.п. Тем не менее представляется, что кучкабали, охватывавшие значительные территории, заселенные десятками тысяч человек, в отличие от кахов были самодостаточны с точки зрения сохранения политической сложности и эффективности эксплуатации населения (примером чему может служить весьма обособленная, но не утратившая сложности полития ица в Петене).

Однако каковы основания полагать, что политическая и административная система, сложившаяся к приходу испанцев, существовала - разумеется, под сенью еще одного верховного политического центра - в эпоху Майяпанской державы?

В отличие от представления Р. Ройса о «провинциях» как остатках административной системы государства с центром в Майяпане, в целом опровергнутого в последние годы, второе его утверждение - о непременном и повсеместном присутствии между кахом и центральной властью прослойки в виде кучкабаля - разделяется большинством майянистов до сих пор (см. напр., 1. Р. 14-27]). Бытует и прямо противоположная точка зрения, допускающая «внезапное» появление кучкабалей сразу вслед за разрушением Майяпана и, таким образом, низводящая сам Майяпан до уровня своеобразного «большого кучкабаля», власть которого опиралась непосредственно на кахи [34. Р. 132]. Обе эти версии представляются в равной степени ошибочными.

Весьма вероятно, что центральное правительство Майяпана вполне могло взаимодействовать с отдельными кахами напрямую. Показателен случай с тяжбой батабов Кавкеля за прибрежные солончаки. Согласно решению Аудиенсии, местные правители сохранили за собой привилегию на получение «подарков» за допуск к соледобыче, которая была предоставлена им еще майяпанским владыкой [6. С. 212]. Можно было бы предположить, что и здесь имелся кучкабаль, а центральные власти действовали напрямую, минуя местного халач-виника по какой-то субъективной причине (например, из-за конфликта с ним). Однако никакого упоминания крупных политических образований в «провинции» Чакан в источниках нет. Более того, само название этой «провинции» переводится с юкатекского попросту как «саванна» [24. С. 79]. Следовательно, говорить о каком-либо политическом или историческом контексте выделения этой «провинции» (например, о вхождении ее в прошлом в какой-либо кучкабаль) не приходится.

В то же время нет оснований делать выводы и об отсутствии кучкабалей в политико-административной системе Майяпанской державы. Наличие у определенных династий контроля над обширными владениями, не уступавшими в размере кучкабалям эпохи конкисты, очевидно. Так, Кокомы в период расцвета гегемонии контролировали двадцать два селения к югу и востоку от Майяпана, не считая самой столицы, - территорию, значительно превышавшую их позднейшие владения в рамках «провинции» Сотута [35]. Вряд ли можно сомневаться в том, что некоторые другие династии, прежде всего Шивы [36], также владели значительными территориями. Об этом говорят хотя бы уже упомянутый выше спор о знатности и предубеждение Кокомов и Шивов по отношению к «выскочкам»- Ч'елям [6. С. 124]. Сомнительно, чтобы двумя главными линиджами исчерпывались майяпанские роды, владевшие кучкабалями.

Представляется, что майяпанская политико-административная система на разных землях была неоднородной, могла быть и пяти-, и четырехуровневой. 
В первом случае речь идет о вхождении в державу относительно крупных региональных государств (кучкабалей), во втором - об инкорпорации отдельных кахов. Эта инкорпорация там, где множество кахов не находилось под управлением одного линиджа, была, очевидно, прямой, через описанное еще у Ланды принудительное проживание представителей или правителей подчиненных земель в столице [6. С. 113]. Следы подобной системы (конечно, на более мелком уровне) можно найти в кучкабале Калькини («провинция» АхКануль), батабы которого имели постоянные резиден- ции в столице из-за необходимости участвовать в работе совета при правителе [24. С. 180]. Однако неравенство между влиятельными родами, владевшими десятками селений, и отдельными батабами (или даже представителями нескольких кахов, если таковые имелись) было чересчур велико. Несмотря на отсутствие четко выраженной царской власти и принцип «совместного правления» (юк. mul tepal) правителей всех подчиненных земель, политическая система Майяпанской державы зависела от борьбы за гегемонию между несколькими наиболее могущественными линиджами.

\title{
ПРИМЕЧАНИЯ
}

\begin{abstract}
${ }^{1}$ «Сообщения» из различных поселений, рассматриваемые здесь и далее - документы из корпуса так называемых «Историко-географических сообщений с Юкатана» [9], составленных испанскими колонистами по приказу Филиппа II в 1579-1581 гг. Корпус насчитывает 50 «Сообщений», касающихся географических особенностей, хозяйственного уклада, истории и этнографии региона.

${ }^{2}$ Вилья - в Испании и ее колониальных владениях особый тип муниципального образования, не обладавший всеми правами и привилегиями города. В XVI в. на Юкатане существовал лишь один город (Мерида) которому в административном плане были подчинены три вильи (СанФрансиско-де-Кампече, Вальядолид и Саламанка-де-Бакалар).

3 Энкомендеро - владелец энкомьенды; энкомьенда - право на получение ренты (отработочной, товарной или денежной) с определенной группы (поселения или его части) индейцев на основании помощи в ее христианизации.

${ }^{4}$ Сенот - карстовый провал в известняковой породе, открывающий доступ к подземным водам; главный источник воды в северной части Юкатана, не имеющей открытых водоемов.
\end{abstract}

\section{ЛИТЕРАТУРА}

1. Quezada S. Maya lords and lordships. Norman, 2014

2. Patel S.U. Journey to the east: Piligrimage, politics, and gender in Postclassic Mexico : PhD diss. Berkeley, 2012.

3. Palka J.W. Maya pilgrimage to ritual landscapes: Insights from archaeology, history, and ethnography. Albuquerque, 2014.

4. Masson M.A., Cepecs S. Political organization in Yucatán and Belize // The Postclassic mesoamerican world / ed. by M.E. Smith and F.F. Berdan. Salt Lake City, 2003. P. 40-44.

5. Folan W.J. The political and economic organization of the Lowland Maya // Mexicon. 1980. Vol. 2, n. 5. P. 73-77.

6. Ланда Д. Сообщение о делах в Юкатане. М. -Л., 1955.

7. Roys R.L. The political geography of the Yucatan Maya. Washington, 1957.

8. Okoshi Harada T. Tenencia de la tierra y territorialidad: conceptualización de los mayas yucatecos en vísperas de la invasión española // Conquista, transculturación y mestizaje: Raíz y orígen de México / ed. por L. Ochoa. México, 1995. P. 81-89.

9. Relaciones Histórico-Geográficas de la Gobernación de Yucatán (Mérida, Valladolid y Tabasco) / ed. por M. de la Garza et al. México, 1983. T. 1-2.

10. Gabbert W. Becoming Maya: Ethnicity and social inequality in Yucatán since 1500. Tucson, 2004.

11. Федюшин В.В. Доиспанская политическая организация майя северного Юкатана в представлении европейских колонистов 2-й пол. XVI в. // Этнографическое обозрение. 2017. № 2. С. 93-105.

12. Bocabulario de Maya Than. Codex Vindobonensis N.S. 3833. Facsímil y transcripción crítica anotada. / ed. R. Acuña. México, 1993.

13. Arzápalo Marín R. Calepino de Motul. Diccionario maya-español. México, 1995.

14. Diccionario maya-español de Ticul / ed. J. Pío Pérez. Mérida, 1870.

15. de Ciudad Real A. Diccionario de Motul (español-maya). Motul, s.n. [manuscrito].

16. Cook S.F., Borah W. Essays in Population History: Mexico and the Caribbean. Berkeley, 1974. Vol. 2.

17. Jones G.D. The conquest of the last Maya kingdom. Stanford, 1998.

18. de Vos J. La paz del Dios y del Rey: La conquista de la selva lacandona, 1525-1821. México, 1993.

19. Bolles D. The Mayan Franciscan vocabularies: A preliminary survey. S.n., 2003.

20. Bolles D. A translation of the edited text of Post Conquest Mayan literature. Lancaster, 2003.

21. Memoria de la distribución de los montes (Maní a 15 de agosto de 1557) // Papeles de los Xiu de Yaxá, Yucatán / ed. por S. Quezada y T. Okoshi Harada. México, 2001. P. 55-65.

22. Códice de Calkiní / ed. por T. Okoshi Harada. México, 2009.

23. Rice P.M. The Kowoh in geopolitico-ritual perspective // The Kowoj: Identity, migration, and geopolitics in Late Postclassic Petén, Guatemala / ed. by P.M. Rice and D.S. Rice. Boulder, 2009. P. 21-54.

24. Пакин А.В. Социально-политическая организация общества юкатанских майя в конце позднего постклассического периода (1441-1541 гг.) : дис. .... канд. ист. наук. М., 2014.

25. Okoshi Harada O. Ch'ibal y cuuchcabal: Una consideración sobre su función en la organización política de los mayas yucatecos del poslcásico // El depliegue del poder entre los mayas: Nuevos estudios sobre la organización política / ed. por A. L. Izquierdo y de la Cueva. México, 2011. P. 207-224.

26. Papeles de los Xiu de Yaxá / ed. por S. Quezada y T. Okoshi Harada. México, 2001.

27. Гуляев В.И. Города-государства майя (структура и функции города в раннеклассовом обществе). М., 1979.

28. Scholes F.V., Roys R.L. Los chontales de Acalán-Tixchel. México, 1996.

29. Gubler R. Datos genealógicos inéditos del linaje Cocom de Yucatán // Mesoamérica. 1993. Vol. 14, № 25. P. 115-133.

30. Kepecs S. Mayas, Spaniards, and salt: World systems shift in Sixteenth-century Yucatán // The Postclassic to Spanish-Era transition in Mesoamerica: Archaeological perspectives / ed. by S. Kepecs and R.T. Alexander. Albuquerque, 2005. P. 117-138.

31. Кнорозов Ю.В. «Сообщение о делах в Юкатане» Диэго де Ланда как историко-этнографический источник // Ланда Д. Сообщение о делах в Юкатане. М. -Л., 1955. С. 3-96.

32. Masson M.A., Peraza Lope C. Kukulcan's realm: Urban life at Ancient Mayapán. Boulder, 2014.

33. Пакин А.В. Дань в обществе юкатанских майя // Развитие цивилизации и Новый Свет : Первые Кнорозовские чтения. / отв. ред. А.П. Логунов. M., 1999. C. 67-68.

34. Vargas Pacheco E. Cabecera, unidad y esfera política: Dinámica de la provincia de Acalán // Nuevas perspectivas sobre la geografía política de los mayas / ed. por T. Okoshi Harada, L.A. Williams-Beck y A.L. Izquierdo. México, 2006. P. 127-158. 
35. Gubler R. Primus inter pares: The ruling house of Cocom // INDIANA. 2001. Vol. 17/18. P. 239-268.

36. Okoshi Harada O. El cúuchcabal de los Xiu: Análisis de su formación y consolidación. // Contributions in New World archaeology. 2012. Vol. 4. P. 229-249.

Fedyushin Vladislav V. Moscow State University (Moscow, Russia). E-mail: vladfedyushin@ gmail.com ON THE STRUCTURE OF MAYAPAN STATE ADMINISTRATIVE SYSTEM

Keywords: Maya; Yucatan; Postclassic period; political structure.

The article discusses the administrative system of the Mayapan state, a regional Late Postclassic Maya hegemony that controlled an extensive area of the Northern Yucatan. My objective is to reconstruct the hierarchy of administrative tiers of this early state. To achieve this, the examining of the main elements of sociopolitical and geographical organization among the Yucatec Maya of the Contact period (i.e., "province", cuchcabal, cah, cuchteel, cacab, and extended family) - with the emphasis on supralocal, the most unstable structures is supposed. The sources used are of Early Colonial origin. These are Diego de Landa's Relación de las cosas de Yucatán, the corpus of Relaciones de Yucatán of 1579-81, a number of Franciscan dictionaries (Calepino and Diccionario of Motul, Bocabulario de Maya Than, and Diccionario de Ticul), and documents from the local noble dynasties' (Cocom, Xiu, and Canul) archives. I conclude that: 1) Contactperiod "provinces" of Yucatan in most cases demonstrate no continuity with the former second-rank supralocal polities subjugated to Mayapan. Some of them (Mani, Sotuta, etc.) could probably have some Mayapan-era prototypes, albeit different in scales and contours. A number of other "provinces" (Chakan, Ah Kin Chel, etc.) obviously cannot be linked to any supposed subpolity inserted into Mayapan state. 2) Still, such polities undoubtedly existed along with directly subjected local structures (cah) as did Caucel whose rulers in the middle of the $16^{\text {th }}$ century pretended to hold a privilege granted by the Mayapan government. 3) The administrative system of the Mayapanled hegemony lacked uniformity. Depending on specific conditions (absence or existence of a supralocal polity analogous to the $16^{\text {th }}$ century cuchcabal) it could have 4 or 5 hierarchical tiers. The second variation was possible if there was in the region a supralocal polity analogous to the $16^{\text {th }}$ century cuuchcabal, a sort of quite extensive early state with a population of several tens of thousands. 4) Cah, a type of geographically and politically organized community having its own settlement center and rural zone as well as its own military and bureaucratic organization was the basic territorial and political unit. 5) Cah was divided into village communities called cuchteelob that were primarily social, and not political, organizations. They could recourse to independent political activity only in anomalous conditions, and it used to be limited to synecism and subsequent formation of a new cah. This articulation by cuchteelob probably used to coincide with the simultaneous infra-cah geographical division by rural settlements called cacabob.

\section{REFERENCES}

1. Quezada, S. (2014) Maya lords and lordships. Norman: University of Oklahoma.

2. Patel, S.U. (2012) Journey to the east: Piligrimage, politics, and gender in Postclassic Mexico. PhD diss. Berkeley.

3. Palka, J.W. (2014) Maya pilgrimage to ritual landscapes: Insights from archaeology, history, and ethnography. Albuquerque: University of New Mexico Press.

4. Masson, M.A. \& Cepecs, S. (2003) Political organization in Yucatán and Belize. In: Smith, M.E. \& Berdan, F.F. (eds) The Postclassic mesoamerican world. Salt Lake City: The University of Utah Press. pp. 40-44.

5. Folan, W.J. (1980) The political and economic organization of the Lowland Maya. Mexicon. 2(5). pp. 73-77.

6. Landa, D. (1955) Soobshchenie o delakh v Yukatane [Report on affairs in Yucatan]. Translated from Spanich by Yu. Knozorov. Moscow; Leningrad: USSR AS.

7. Roys, R.L. (1957) The political geography of the Yucatan Maya. Washington: Carnegie Institution of Washington.

8. Okoshi, H.T. (1995) Tenencia de la tierra y territorialidad: conceptualización de los mayas yucatecos en vísperas de la invasión española [Land tenure and territoriality: conceptualization of the Yucatec Maya on the eve of the Spanish invasion]. In: Ochoa, L. (ed.) Conquista, transculturación y mestizaje: Raiz y orígen de México [Conquest, transculturation and miscegenation: Root and origin of Mexico]. México: Universidad Nacional Autónoma de Méxic. pp. 81-89.

9. Garza, M. de la et al. (eds) (1983) Relaciones Histórico-Geográficas de la Gobernación de Yucatán (Mérida, Valladolid y Tabasco) [Historical-Geographical Relations of the Government of Yucatán (Mérida, Valladolid and Tabasco)]. Vol. 1-2. México: Universidad Nacional Autónoma de México.

10. Gabbert, W. (2004) Becoming Maya: Ethnicity and social inequality in Yucatán since 1500. Tucson: University of Arizona Press.

11. Fedyushin, V.V. (2017) Pre-Hispanic Political Organization of the Northern Yucatan Maya in the Views of the Late 16th Century European Colonists. Etnograficheskoe obozrenie - Ethnographic Review. 2. pp. 93-105. (In Russian).

12. Acuña, R. (1993) Bocabulario de Maya Than. Codex Vindobonensis N.S. 3833. Facsímil y transcripción crítica anotada. México: Universidad Nacional Autónoma de México.

13. Arzápalo, M.R. (1995) Calepino de Motul. Diccionario maya-español [Calepino de Motul. Mayan-Spanish dictionary]. México: Universidad Nacional Autónoma de México.

14. Pío Pérez, J. (ed.) (1870) Diccionario maya-español de Ticul [Mayan-Spanish Dictionary of Ticul]. Mérida: [s.n.]

15. Ciudad Real, A. de (n.d.) Diccionario de Motul (español-maya) [Dictionary of Motul (Spanish-Mayan)]. Motul: [s.n.]. [Manuscript].

16. Cook, S.F. \& Borah, W. (1974) Essays in Population History: Mexico and the Caribbean. Vol. 2. Berkeley: University of California Press.

17. Jones, G.D. (1998) The conquest of the last Maya kingdom. Stanford: Stanford University Press.

18. de Vos, J. (1993) La paz del Dios y del Rey: La conquista de la selva lacandona, 1525-1821 [The peace of God and the King: The conquest of the Lacandon jungle, 1525-1821]. México: Secretaría de Educación y Cultura de Chiapas.

19. Bolles, D. (2003) The Mayan Franciscan vocabularies: A preliminary survey. [s.1.; s.n.].

20. Bolles, D. (2003) A translation of the edited text of Post Conquest Mayan literature. Lancaster: [s.n.].

21. Quezada y T, S. \& Okoshi Harada, T. (2001) Memoria de la distribución de los montes (Maní a 15 de agosto de 1557) [Memory of the distribution of the mountains (Maní to August 15, 1557)]. Papeles de los Xiu de Yaxá, Yucatán. pp. 55-65.

22. Okoshi Harada, T. (2009) Códice de Calkini [Calkiní Codex]. México: [s.n].

23. Rice, P. M. (2009) The Kowoh in geopolitico-ritual perspective. In: Rice, P.M. \& Rice, D.S. (2009) The Kowoj: Identity, migration, and geopolitics in Late Postclassic Petén, Guatemala. Boulder: University Press of Colorado. pp. 21-54.

24. Pakin, A.V. (2014) Sotsial'no-politicheskaya organizatsiya obshchestva yukatanskikh mayya v kontse pozdnego postklassicheskogo perioda (1441$1541 \mathrm{gg}$.) [Socio-political organization of the Yucatan Mayan society at the end of the late postclassical period (1441-1541)]. History Cand. Diss. Moscow.

25. Okoshi Harada, O. (2011) Ch'ibal y cuuchcabal: Una consideración sobre su función en la organización política de los mayas yucatecos del poslcásico [Ch'ibal and cuuchcabal: A consideration of their role in the political organization of the Yucatecan Mayas of the post-Classic]. In: Izquierdo y de la Cueva, A.L. (2011) El depliegue del poder entre los mayas: Nuevos estudios sobre la organización política [The deployment of power among the Maya: New studies on political organization]. México: Universidad Nacional Autónoma de México. pp. 207-224. 
26. Quezada, S. \& Okoshi Harada, T. (eds) (2001) Papeles de los Xiu de Yaxá [Papers of the Xiu de Yaxá]. México: Plaza y Valdes.

27. Gulyaev, V.I. (1979) Goroda-gosudarstva mayya (Struktura i funktsii goroda v ranneklassovom obshchestve) [Maya City States (Structure and functions of a city in an early class society)]. Moscow: Nauka.

28. Scholes, F.V. \& Roys, R.L. (1996) Los chontales de Acalán-Tixchel [The chontales of Acalán-Tixchel]. México: CIESAS.

29. Gubler, R. (1993) Datos genealógicos inéditos del linaje Cocom de Yucatán [Unpublished genealogical data of the Cocom de Yucatán lineage]. Mesoamérica. 14(25). pp. 115-133.

30. Kepecs, S. (2005) Mayas, Spaniards, and salt: World systems shift in Sixteenth-century Yucatán. In: Kepecs, S. \& Alexander, R.T. (eds) The Postclassic to Spanish-Era transition in Mesoamerica: Archaeological perspectives. Albuquerque: University of New Mexico Press. pp. 117-138.

31. Knorozov, Yu. V. (1955) "Soobshchenie o delakh v Yukatane" Diego de Landa kak istoriko-etnograficheskiy istochnik ["Report on the affairs in the Yucatan" Diago de Landa as a historical and ethnographic source]. In: Landa, D. (ed.) Soobshchenie o delakh v Yukatane [Report on affairs in Yucatan]. Translated from Spanich by Yu. Knozorov. Moscow; Leningrad: USSR AS. pp. 3-96.

32. Masson, M.A. \& Peraza Lope, C. (2014) Kukulcan's realm: Urban life at Ancient Mayapán. Boulder: University Press of Colorado.ed.

33. Pakin, A.V. (1999) Dan' v obshchestve yukatanskikh mayya [Tribute in the society of the Yucatan Maya]. In: Logunov, A.P. (ed.) Razvitie tsivilizatsii i Novyy Svet: Pervye Knorozovskie chteniya [Development of civilization and the New World: The first Knorozov readings]. Moscow: Russian State University for the Humanities. pp. 67-68.

34. Vargas Pacheco, E. (2006) Cabecera, unidad y esfera política: Dinámica de la provincia de Acalán [Head, unit and political sphere: Dynamics of the province of Acalan]. In: Okoshi Harada, T., Williams-Beck, L.A. \& Izquierdo, A.L. (eds) Nuevas perspectivas sobre la geografia politica de los mayas [New perspectives on the political geography of the Maya]. México: UNAM. pp. 127-158.

35. Gubler, R. (2001) Primus inter pares: The ruling house of Cocom. INDIANA. 17/18. pp. 239-268. DOI: 10.18441/ind.v17i0.239-267

36. Okoshi Harada, O. (2012) El cúuchcabal de los Xiu: Análisis de su formación y consolidación [The cúuchcabal of the Xiu: Analysis of their formation and consolidation]. Contributions in New World Archaeology. 4. pp. 229-249. 